\title{
Leonard K. Comments on the Nexus 2000 Round Table Eaton Discussion
}

The author reflects on the Nexus 2000 Round Table Discussion "Methodology in Architecture and Mathematics" and on the relationships of architecture and mathematics through history.

My reactions to the excellent round table discussion led by Carol Watts at Nexus 2000 in Ferrara on 6 June 2000 [Watts 2000] are conditioned by two factors. (1) I took my graduate degree in an interdisciplinary program at Harvard University in 1946-50. This program required the student to demonstrate competence in certain fields such as American social history, the history of American literature, the history of American art and architecture, etc. I therefore knew very well that there was such a field as the history of mathematics, but at the time had no reason to dig into it. (2) For 38 years a large part of my academic task was to teach a two-semester survey course on the history of Western architecture. It ran roughly from the ancient Greeks to Thomas Jefferson. I believed that it was part of my responsibility to be aware of the latest scholarship in the ancient, medieval, Renaissance, and Baroque fields - even though I could not lay claim to real expertise in any of them.

Because of these two aspects of my academic experience I have come to see the history of architecture and the history of mathematics as two streams that are generally parallel and sometimes tangent. When they have been tangent, the meeting has usually been occasioned by the question of proportion. Architects in the ancient world were much concerned with this issue. The literature on the tangency is abundant. When I was teaching, I tended to rely on William Bell Dinsmoor's Architecture of Ancient Greece, which was for many years canonical. Dinsmoor's approach was essentially archaeological, but he was very much interested in mathematical problems. When I heard him give the Jerome lectures at Ann Arbor, Michigan, in the nineteen fifties, he delivered some pithy comments on Le Corbusier's Modulor. It is unfortunate that these remarks were never published. If Dinsmoor had given them to the world, a large amount of nonsensical writing might have been avoided.

In recent years our knowledge of the interaction of architecture and mathematics in the ancient world has increased. At Nexus 2000, Rocco Leonardis satisfied me, at any rate, that the Greek temples of Sicily and Italy are, "loaded with Pythagorean mathematics" (I think I have quoted him correctly). Similarly, at Nexus '98, Gert Sperling gave an impressive account of the mathematics incorporated in Hadrian's Pantheon. His findings are now available in a German text [Sperling 1999].

Matters seem to have changed substantially with the fall of the Western Roman Empire and the advent of the Middle Ages. Except in the Byzantine East, there does not seem to have been a great deal of interaction between mathematics and architecture during this 
long period. No one can doubt the mathematical capabilities of Anthemius of Tralles and Isidorus of Miletus, who were Justinian's architects for the great church of Hagia Sophia at Istanbul (532-537). It is notable, however, that in the long history of Eastern Empire, no emperor and no architect ever tried anything of this brilliance and originality again. The formula of a cross in square surmounted by a dome became canonical with the Byzantine. Throughout the long and complex history of the Empire and of the states associated with it, this form was continually repeated.

In Western Europe during the Middle Ages there was a great deal of magnificent building but very little development of the theoretical side of mathematics. Granted that the Fibonacci series was a medieval discovery, one would be hard put to cite a medieval building which included that series. Of course the master masons who built the Gothic cathedrals were excellent geometers. Any one who plows through the two volumes of John James's The Contractors of Chartres [1976] will develop a profound respect for the practical geometric capabilities of its builders. Indeed, it is highly probable that the "secrets" of the masons' lodges were geometrical theorems. But the members of these lodges did not write treatises. In a sense, their structures are embodiments of geometry in stone. The same comment can be made about the Italian pavements so brilliantly discussed by Kim Williams [1997]. They are mathematical statements on tiling. Her measurements reveal the intricacy of the designers' thoughts - but there are no treatises. Occasionally we find an overtly mathematical structure such as the Castel del Monte in Apulia, discussed by Heinz Götze at Nexus '96, but these are exceptions to the general rule, and in this structure the Indo-Arabic connection is very strong. For the most part, medieval master masons and their royal and ecclesiastical patrons were content with a very practical kind of geometry. Part of the problem may have been that the mathematicians of the period mostly worked in monasteries. There were no printed books, and new mathematical discoveries would have made their way into general intellectual discourse only slowly. I conclude that for almost a thousand years the stream of architecture and mathematics were parallel and very seldom tangent. The situation changed dramatically with the advent of the Renaissance and the invention of the printing press.

To a considerable extent Renaissance architecture was a book architecture, and a large number of the most influential books dealt with the problem of obtaining good proportions in a building. I have always believed that the famous five orders of Serlio, et al, were, in a sense, simply a way of obtaining good proportions. In Architectonics of Humanism [1998] Lionel March spends a great deal of time analysing the various kinds of mathematics that were incorporated into Renaissance treatises on the building art (Steve Wassell properly remarked that this book was the most important contribution to the field since Wittkower). The point I stress is that the period 1400-1700 was one in which European mathematicians made giant strides and that these strides now became a part of wider intellectual discourse through the medium of books. Mathematicians and scientists became major figures in the intellectual life of their countries in a way that had never been true before. The careers of Galileo, Newton and Descartes immediately come to mind. And these men not only made huge contributions on their own, but were also popularizers who brought their achievements to the attention of a wider audience, presumably including artists and architects. Thus it can be argued that the great buildings 
of the Baroque age reflected mathematical thought in a way that medieval buildings never did. Thus at Nexus '96 John Claggett remarked, "Looking at the complex intersections and symmetries of the Central European Baroque structures, it is clear that their architects were extremely advanced in their ability to measure and manipulate curving surfaces and to grasp indeterminate, abstract spatial order, not to mention to map such curves and find their tangents". It would appear that the tangency of the two streams lasted well into the eighteenth century.

In this connection I will observe that the last few pages of Wittkower's Architecture of Humanism can be interpreted as a melancholy story. The author noted that in England "...the whole structure of classical aesthetics was overthrown from the bottom" [Wittkower 1980: 150]. Hume and Burke were the leaders of the attack, and Alison and Richard Payne Knight carried it on into the early nineteenth century. In the English-speaking world perhaps the chief culprit was John Ruskin, who held that possible proportions are as infinite as the airs in music and encouraged artists to invent beautiful proportions. When we consider the vast influence of Ruskin in England and America, this was an horrendous declaration. For Ruskin, who hated the Renaissance, the streams of mathematics and architecture were as separate as they had been in the Middle Ages. British architects were left with no theory of proportion when they undertook the huge building projects of the Victorian Age. This deficiency is perhaps one of the reasons why these projects were execrated for so many years.

Relief began to appear in an unexpected quarter when Gustav Theodor Fechner published his seminal article, "Über die mathematische Behandlung organischer Gestalten und Processe" [Fechner 1849]. Fechner's mathematical approach to the problems of biological form was picked up by Adolf Zeising, who published a classic treatise on the Golden Section [Zeising 1884], in which he attempted to verify scientifically the claims of the golden rectangle. With customary Germanic thoroughness, Zeising made thousands of measurements of commonly seen rectangles. Playing cards, windows, writing paper pads and book covers were among the objects he measured. He found that the average was close to phi. Zeising thereby launched a long series of investigations that attempted to demonstrate the scientific basis for the human preference for the golden rectangle. Such investigations became an important part of Gestalt psychology. Perhaps the best known of these is Matila Ghyka's Geometry of Art and Life [1977], but the most provocative to my mind is D'Arcy Thompson's On Growth and Form [1992]. More recently Jay Kappraff's Connections [1991] is another praiseworthy demonstration of the link between architecture and mathematics. So there is a good foundation for any designer who wants to develop an architecture based on new (or old) mathematics.

In the twentieth century the leaders of the architectural profession were generally aware of the importance of mathematics. In An Autobiography, Frank Lloyd Wright wrote that "From the very beginning my T-square and triangle were easy media of expression for my geometrical sense of things" [Wright 1946: 95]. In my view, however, research on Wright's relationship to mathematics has only begun. I have myself tried to analyze it in some of his windows [Eaton 2000], as has Professor Lionel March. With Wright the problem is difficult because he lived a long time, experimented constantly, used several 
different geometries, and ended up with something very close to fractals. Professor March and I have worked on his windows, probably because they are relatively easy to measure. I suspect that the next step is a careful measurement and analysis of some of Wright's furniture. When these results are in, we might progress to the mathematical analysis of entire buildings.

Everybody knows about Le Corbusier and his Modulor. It is simply a double scale of lengths which Corb called the red and blue series. The blue series is a Fibonacci sequence with all consecutive segments approaching a golden ratio to each other as the series is extended. The red series is constructed so that each length is the arithmetic mean of successive lengths of the blue series that brace it [Kappraff 1991: 22]. Kappraff remarks that the Modulor satisfies the three canons of proportion: "It provides a small number of modules capable of tiling a given rectangular space; the modules all have proportions based on the golden mean, ensuring repetition; and the system has sufficient versatility to enable the designer to find interesting subdivisions" [Kappraff 1991: 24]. Nonetheless the scale has not been much used in designing complete buildings, perhaps because it is too coarse and leaves large gaps at important points in the design. It seems to be useful mainly as a theoretical tool. Robin Evans observed that the Modulor is present throughout the chapel at Ronchamp [Evans 1995: 273-274]. This building may be the exception to the rule. Like most of Le Corbusier's work, the Modulor does not seem to have appealed to architects on the American side of the Atlantic. The reasons for our negative attitude toward this architect are problematical. They are probably deeply imbedded in our culture.

The views of Mies Van Der Rohe on matters of proportion are difficult to assess. The admiration of Mies for Schinkel is well known. This preference may have something to do with the fact that Schinkel was rarely guilty of an error in proportion. The reluctance of Mies to comment on his design methodology is also well known. I once asked a colleague who had worked closely with Mies on the initial design of the campus for Illinois Institute of Technology about the choice of a 12' x 12' x 24' module for the buildings. My friend, an excellent architect, had not the slightest idea of the reasons behind the choice of this mathematically provocative module. It is suggestive that Rachel Fletcher found a golden section in the elevation of Philip Johnson's Glass House, done at the time when Johnson was in his most Miesian phase. Obviously a great deal more needs to be done on the mathematical aspect of Mies.

Which leads me to another point: In the twentieth century the relationship of architecture and mathematics for many architects was resumed - but we are only at the beginning of the work necessary to trace this development. Probably the crucial event was the appearance of Rudolph Wittkower's Architectural Principles in the Age of Humanism. The initial publication of this work was in 1949; subsequent editions and articles reinforced the author's argument. Happily Professor Wittkower lived to see his arguments taken with the utmost seriousness by historians and critics of all varieties. The creation of the Nexus enterprise is, in a sense, a tribute to Wittkower. Without his stimulus we might not have noticed that, in the twentieth century, the tangency of architecture and mathematics has reoccurred.

10 Leonard K. Eaton - Comments on the Nexus 2000 Round Table Discussion 
Finally I return to a point made during the round table led by Carol Watts: In any measurements we make of buildings done at any epoch, we must be sure that we are aware of the measuring tools which were available to architects and artisans, whether they worked in the Middle Ages or the twentieth century. If we do not follow this precept, we may well attribute to a design a mathematical sophistication which does not exist.

\section{References}

Clagett, John. 1996. Transformational Geometry and the Central European Baroque Church. Pp. 37-51 in Nexus: Architecture and Mathematics. Kim Williams, ed. Fucecchio (Florence): Edizioni dell'Erba.

Dinsmoor, William Bell. 1973. Architecture of Ancient Greece. Biblo-Moser.

Eaton, Leonard K. 2000. Mathematics and Music in the Art Glass Windows of Frank Lloyd Wright. Pp. 57-71 in Nexus III: Architecture and Mathematics. Kim Williams, ed. Pisa: Pacini Editore.

Evans, Robin. 1995. The Projective Cast: Architecture and Its Three Geometries. Cambridge, MA: MIT Press.

Fechner, Gustav Theodor. 1849. Über die mathematische Behandlung organischer Gestalten und Processe. Pp. 50-64 in Berichte sachs Gesellsch, Math-phys. Cl. Leipsig.

Ghyka, Matila. 1977. The Geometry of Art and Life. 1946. rpt. New York: Dover Publications.

Kappraff, Jay. 1991. Connections: The Geometric Bridge Between Art and Science. New York: McGraw-Hill.

March, Lionel. 1998. Architectonics of Humanism: Essays on Number in Architecture. London: Academy Editions.

Sperling, Gert. 1999. Das Pantheon in Rom: Abbild un Mass des Kosmos. Neuried: Ars Una.

. 1998. The Quadrivium in the Pantheon of Rome. Pp. 128-142 in Nexus II: Architecture and Mathematics. Kim Williams, ed. Fucecchio (Florence): Edizioni dell'Erba. Thompson, D'Arcy. 1992. On Growth and Form. Cambridge: Cambridge University Press.

Watts, Carol Martin. 2000. Methodology in Architecture and Mathematics. Nexus Network Journal 2: 105-130.

Williams, Kim. 1997. Italian Pavements: Patterns in Space (Houston: Anchorage Press, 1998).

Wittkower, Rudolf. 1998. Architectural Principles in the Age of Humanism. New York: John Wiley and Sons, 1998.

Wright, Frank Lloyd. 1946. An Autobiography. London.

Zeising, Adolf. 1894. Der Goldene Schnitt.

Nexus Network Journal - vol. 3, No 2, 2001 


\begin{abstract}
About the author
Leonard K. Eaton is Emil Lorch Professor of Architecture Emeritus, the University of Michigan, where he taught architectural history from 1950 to 1988. He has also taught at Wayne State University, Michigan State University, and the University of Victoria (British Columbia). In 1985 he was Morgan Professor at the University of Louisville. He took his B.A. with highest honors at Williams College in 1943, and after war service with the 10th Mountain Division, received an M.A. and Ph.D. from Harvard University. His publications include: Landscape Artist in America: the Life and Work of Jens Jensen (1964), Two Chicago Architects and their Clients (1969), American Architecture Comes of Age (1972) and Gateway Cities and Other Essays (1989). He is best known for his work on Frank Lloyd Wright, he has presented two papers at Nexus conferences, "Fractal Geometry in the Late Work of Frank Lloyd Wright: the Palmer House" (Nexus 98) and "Mathematics and Music in the Art Glass Windows of Frank Lloyd Wright" (Nexus 2000). Prof. Eaton is the author of "Hardy Cross and the Moment Distribution Method" in the present volume of the $N N J$.
\end{abstract}

12 Leonard K. Eaton - Comments on the Nexus 2000 Round Table Discussion 